\title{
The Effects of Green Tea and Propolis Extracts on pro-inflammatory cytokines TNF- $\alpha$, IFN- $\gamma$, IL2, and Immunoglobulin Production in Experimentally Infected Rabbits with Bovine Herpesvirus-1
}

\author{
Gamil Sayed Gamil Zeedan ${ }^{1 *}$, Khaled Abd El-Hamid Abd El-Razik ${ }^{2}$, Sobhy Abdel-Shafy ${ }^{1}$, Tarek KorenyFarag ${ }^{1}$ \\ and Ayman Hamid Mahmoud ${ }^{3}$
}

\author{
${ }^{1}$ Parasitology and Animals Diseases Department, National Research Centre,33 Bohouth St., Dokki, Giza, P.O. box 12622, Egypt \\ ${ }^{2}$ Reproduction diseases department, National Research Centre, 33 Bohouth St., Dokki, Giza, P.O. box 12622, Egypt \\ ${ }^{3}$ Biotechnology and Food hygiene department, Animal Health Institute, Dokki Giza, Egypt
}

*Corresponding author`s Email: Gamil Sayed Gamil Zeedan, e-mail: gamilzee@ yahoo.com; (DORCiD: 0000-0002-2723-542X

\begin{abstract}
Bovine herpesvirus 1 (BHV-1) is a highly contagious viral pathogen which causes infectious bovine rhinotracheitis in bovine worldwide. Currently, there is no antiviral prophylactic treatment available capable of the complete cure of the viral disease and facilitating recovery from latent infection in animals. The present study aimed to evaluate antiviral activities of Water Green Tea Extract (WGE) and Ethanol Propolis Extract (EPE) against BHV-1 virus comparing to commercial Acyclovir (ACV) in vitro in Madin-Darby Bovine Kidney (MDBK) cell line and in vivo in rabbits as a laboratory animal's model. The cytotoxicity assay was determined the safe dose of water green tea, and Ethanol propolis extracts and evaluated antiviral activity of each extract on infected MDBK with BHV-1. The fifteen rabbits were divided accidentally into five groups. Groups 1,2 and 3 were inoculated with BHV-1 virus $10^{7}$ TCID50/250 ul in nostrils and received propolis ethanol, water green tea extracts and ACV antiviral for 7 dpi respectively. Group 4 was inoculated with BHV-1 virus 107 TCID50/250 ul in nostrils without extracts or commercial drug. Group 5 was considered as control negative. Results of in-vitro study showed water green tea, and ethanol propolis extracts were potent inhibitor on BHV-1, which showed $80 \%$ protection against this virus and dropped in viral titer more than ACV. In vivo study of treated infected animals with WGE, EPE and ACV reduced clinical signs, elevated cytokines, and antibody production levels and failed re-isolated or detect DNA in blood or nasal samples swabs. Non treaded infected rabbits group developed respiratory clinical signs, humoral response and re-isolated BHV-1 and detected viral DNA of BHV-1 in blood, and nasal swabs from experimentally infected rabbits. In conclusion, propolis and green tea extracts were able to prevent virus replication and reduced CPE in MDBK cell cultures infected with BHV-1 and able to induce cytokines and antibodies levels production.
\end{abstract}

Key words: Acyclovir, BHV-1, ELISA, Green tea, Propolis

\section{INTRODUCTION}

Bovine herpesvirus-1 (BHV-1) belongs to the Varicellovirus genus of the Alphaherpesvirinae subfamily within the Herpesviridae family (Diallo et al., 2011). The viral genome consists of double-stranded DNA that codes for about 70 proteins, of which 33 are known to be structural and up to 15 are non-structural proteins (Muylkens et al., 2007). The viral glycoproteins are located in the envelope on the surface of the virion and play an important role in pathogenesis and immunity. BHV-1 can be differentiated into subtypes 1.1, 1.2a, 1.2b and 1.3 (Muylkens et al., 2007). BHV-1 is a cause of several infectious disease syndromes in cattle and buffaloes and occurs throughout the world (Thakur et al., 2017; OIE, 2018). BHV-1 is associated with major clinical syndromes namely, IBR, Infectious Pustular Vulvovaginitis (IPV) and Infectious Pustular Balanoposthitis (IPB) (Jones and Chowdhury, 2010; Pandey et al., 2014). BHV-1 is also a contributing factor in shipping fever, also known as bovine respiratory disease (Wentink et al., 2000). This virus has worldwide economic impact on livestock industry(Kook et al., 2015). In Egypt, since 1960s, attention was drawn to BHV-1 as one of the most significant causes of great economic loss in feedlot and dairy farms, mainly due to death, abortion, weight loss, cost of treatment and prevention (Biswas et al., 2013; Zeedan et al., 2018). BHV-1 control in cattle is based on vaccination and hygienic measures for the herd cattle, quarantine for new cattle (Chung and Hemmatzadeh, 2016; Zeedan et al., 2018). Therefore it becomes so urgent to develop a new-type of natural antiviral with high efficiency and low toxicity (Kuete et al., 2012; Yin et al., 2013; Chung et al., 2016). New antiviral drug research is rapidly growing due to increasing resistance to current antiviral medications. Most antiviral drug research has focused on natural products (Cragg and Newman, 2013; Civitelli et al., 2014). One such product is propolis or bee glue (Vlietinck and Berghe, 1991; Yuqing et al., 2012). Propolis has many pharmacological properties and biological activities, such as anti-inflammatory, antibacterial, antifungal, antioxidant, anticancer, and antiviral effects (Zeedan et al., 2014). Propolis is a resinous material produced by bees that displays a variety of biological activities against viruses (Allison and Byars, 1991). Many actions of propolis are still unknown. Hegazi et al. (2001) investigated the composition of propolis samples 
collected from Upper Egypt. Propolis samples were investigated by GC/MS, 71 compounds were identified, 14 being new for propolis. Banisweif propolis is characterized by the presence of 7 caffeate esters and 4 triterpenoids. Fayoum propolis showed the highest amount of lactic acid and the presence of 3 chalcones. But Assiut propolis is characterized by the presence of 4 prenylated coumar-ates. Souhag propolis is characterized by the presence of 5 aliphatic dicarboxylic acids and some other new compounds to propolis. It has very complex composition more than 300 components have already been identified, and depends upon the original source (Münstedt, 2019; Soós et al., 2019). Propolis consists of complex chemical compounds, the most important group being phenolic acid components, which play a role in antiviral activity. It has been reported that constituents such as caffeic acid, p-coumaric acid, benzoic acid, galangin, pinocembrin, and chrysin may be effective against Herpes Simplex Virus in cell culture (Lirdprapamongkol et al., 2013).

The green tea is a product of the plant Camellia sinensis (Araghizadeh et al., 2013). The flavonoids present in the green tea have two aromatic rings, A and B with hydroxyl groups (Vu et al., 2011). Most of the health benefits of green tea can be attributed to its polyphenols that comprise 25 to $35 \%$ in composition included polyphenols are best known for their diverse biological and pharmacological activities, including anti-oxidative (de Oliveira et al., 2015), antiproliferative (Yin et al., 2013) anti-inflammatory, antibacterial (Anita et al., 2014), and antiviral activities against different Ribonucleic Acid (RNA) and Deoxyribonucleic Acid (DNA) viruses (Araghizadeh et al., 2013).

The green Tea extract inhibited the replication of influenza viruses by preventing acidification of intracellular compartment, such as lysosomes and endosomes (Matsusaki et al., 2016). The present study aimed to evaluate Antiviral activity of water green tea, and Ethanol propolis extracts against BHV-1 virus comparing to Acyclovir (ACV) in vitro in Madin-Darby Bovine Kidney (MDBK) cell culture and in vivo, experimentally BHV-1 infected rabbits by measuring Tumor Necrosis Factor-alpha (TNF- $\alpha$ ), interferon gamma (IFN- $\gamma$ ), IL-2 cytokines and antibody levels.

\section{MATERTIALS AND METHODS}

\section{Ethical approval}

All samples were collected as per standard procedure without giving any stress or harm to the animals and the guidelines of the (NRC, 1996). The study was conducted according to Medical Research Ethical Committee Research, National Statement on Ethical Conduct in Human and animals Research at National Research Centre, Egypt under registration code \# 19-134\#.

\section{Preparation ethanol propolis extract}

Propolis was collected from beehives located in Egypt and stored at $-20^{\circ} \mathrm{C}$. The ethanolic extract was prepared as described by (Paulino de Souza et al., 2018). Briefly, propolis samples were frozen at $-24^{\circ} \mathrm{C}$ and a grinder was used to break them into small pieces. Two grams of propolis were shaken with $20 \mathrm{ml} 70 \%$ ethanol/water (v/v) using a shaker for Propolis was ground and macerated with an extract solution containing absolute ethanol, using 10 minutes (min) daily agitation, for 10 days. The mixture was filtered using filter papers (Watman No: 1) to remove wax and bee parts. Then, the solvent was evaporated and the resulting dried matter was dissolved in phosphate buffer solution (pH 6.2), in a final concentration of $100 \mathrm{mg} / \mathrm{ml}(4 \%, \mathrm{w} / \mathrm{v})$ of propolis, sterilized and stored at $-20^{\circ} \mathrm{C}$

\section{Preparation of water green tea extract}

Dried green tea leaves were purchased from Herbal plants hopping market. Green plant extract was prepared according to Paulino de Souza et al. (2018), small pieces and extracted twice with sterile distilled water for 12 hours (h) at $80^{\circ} \mathrm{C}$, at a ratio of $40 \mathrm{ml}$ water to one $\mathrm{g}$ of the plant. Insoluble material was removed by filtration. The clear supernatant was concentrated by lyophilization, reconstituted with water to $100 \mathrm{mg} / \mathrm{ml}$, sterilized and stored at $-20^{\circ} \mathrm{C}$ until use.

\section{Standard drugs}

Acyclovir (Sigma, USA) was selected as a standard drug. It was dissolved in bi-distillated water before use (1 $\mathrm{mg} / \mathrm{ml}$ ). Various concentrations of propolis and green tea, ranging from 0.5 to $512 \mu \mathrm{g} \mathrm{ml}-1$, were used in the experiments.

\section{Titration of BHV-1 on Madin-Darby Bovine Kidney cell line}

Viruses were titrated in duplicate using MDBK tissue culture infectious dose of 50\% (TCID50\%). Briefly the original stock virus serial tenfold serial dilutions of virus were prepared in sterile vials ranged $10^{-1}$ to $10^{-9}$ using maintenance medium $1 \%$ fetal bovine serum (FBS), $1000 \mathrm{U} / \mathrm{mL}$ of penicillin and streptomycin $10 \mu \mathrm{g} / \mathrm{mL}$ ) were inoculated on ice block as to maintain the viability and titer of the BHV-1. Each virus dilution was distributed into 6 wells (100 ul/well) of monolayer MDBK cells. The 96-well microtiter plate was incubated at $37^{\circ} \mathrm{C}$ with $5 \% \mathrm{CO}_{2}$ for three days till the appearance of the CPE. Determination of $\mathrm{TCID}_{50} / \mathrm{ml}$ was calculated according to the Lee et al. (2015) 


\section{Cytotoxic effect of propolis and green tea extracts, on Madin-Darby Bovine Kidney cell line}

The cytotoxicity of propolis and green tea were determined using a standard in vitro cytotoxicity procedure with minor modifications (Gavanji et al., 2015). Briefly, seven serial two-fold dilutions of extracts were prepared in maintenance media (2\% FBS) and $100 \mathrm{ul}$ of the diluted extracts were added to MDBK cells in a 96-microtiter plates. The plates were incubated for $72 \mathrm{~h}$. The media was removed from the microtiter plates, replaced with 100ul of MEM containing $50 \mathrm{ug} / \mathrm{ml}$ neutral red dyes and incubated for three $\mathrm{h}$ at $37^{\circ} \mathrm{C}$. The dye solution was removed and replaced with $200 \mathrm{ul}$ of a solution containing $1 \%$ acetic acid and $50 \%$ methanol to extract the dye and the plates were incubated for 20 minutes at room temperature. The OD of the neutral red dye was read in a wavelength spectrophotometer at $550 \mathrm{~nm}$. The cytotoxic concentration $\left(\mathrm{CC}_{50}\right)$ was determined as the percentage change in OD and was calculated as follows: 1-[ODt / ODs] Multipy in 100

\section{Animals}

The experiment was carried out at National Research Centre, Dokki, and Giza, Egypt. Rabbits were housed in separate cages, fed on a balanced commercial ration, and water was available ad libitum, randomly divided into 5 groups then housed in wire cages, lighted for $24 \mathrm{~h}$ receiving feeding and water, used in experimental vaccine efficacy. Bleeding of the animals was performed by a puncture in the marginal ear vein after adequate restraint and disinfection of the area. Handling of rabbits and all experimental procedures were performed in compliance with the recommendations of the "Guide for the Care and Use of Laboratory Animals of the National Research Council (NRC, 1996).

\section{Detection of the antiviral effect green tea and propolis extracts against BHV-1}

Confluent monolayer (80-90\%) of MDBK cells was prepared in 96-well microtiter plate. Equal volumes (100 ul) of each extracts at the previously mentioned concentrations and $100 \mathrm{TCID}_{50} / \mathrm{ml}$ of BHV-1 (100ul) were added to the cell monolayer at the same time and the plate was incubated at $37^{\circ} \mathrm{C}$ and $5 \% \mathrm{CO}_{2}$ for 3-4 days. The appearance of Cytopathic Effect (CPE) after 3-4 days was monitored. The plate was stained with neutral red dye like previously mentioned in cytotoxicity test and the effect of plants on BHV-1 virus replication was calculated from the following equations. Dan ve et al., (2002) Virus replication $=[1-\mathrm{OD}$ virus control $]-[1-\mathrm{OD}$ cell control]. Virus replication extract $=[1-(\mathrm{OD}$ virus + extract)]-[1-OD cell control] Percentage of reduction=1-[viral replication extract/viral replication] multiply 100

\section{Experimental design}

New Zealand White rabbits 7-8 weeks of age, with a weight of 1-1.5 kg (n-15) were divided into Five groups (each containing 3 rabbits), 3 group' rabbits receiving intranasal doses of BHV-1 virus $10^{7}$ TCID50/250 $\mu \mathrm{L}$ Group 1 was inoculated with the BHV-1 virus $10^{7}$ TCID50/250 ul in each nostrils and received propolis ethanol extract $50 \mathrm{ug} / \mathrm{kg}$ body weight for seven days post-inoculation, group2 inoculated with water green tea extract $50 \mathrm{mg} / \mathrm{kg}$ body weight for seven days post-inoculation and group3 inoculated with ACV antiviral drug $20 \mathrm{mg} / \mathrm{kg}$ body weight for seven days postinoculation. Group 4 receiving intranasal doses of BHV-1 virus $10^{7}$ TCID50 $/ 250 \mu \mathrm{L}$ positive control and $5^{\text {th }}$-group, inoculated with $250 \mu \mathrm{L}$ inoculated with sterile Phosphate Buffer Saline (PBS) kept as control negative. All animals were observed daily for clinical signs or abnormal observation, rectal temperatures were taken using a digital thermometer and nasal swabs were evaluated for re- isolation. Blood samples were collected from day zero (pre-inoculated), $3 \mathrm{~h}, 6 \mathrm{~h}$, $12 \mathrm{~h}, 1$ day, 2days, 3days, and every week until the end of the experiment. The experiment continue for five weeks, collected (One $\mathrm{ml} /$ rabbit) into Eppendorf tubes and allowed to clot at $37{ }^{\circ} \mathrm{C}$ for one h. Serum was separated by centrifugation then stored at $-20^{\circ} \mathrm{C}$ until used.

\section{Enzyme-linked immunosorbent assay}

The indirect Enzyme-Linked Immunosorbent Assay (ELISA) technique was used for quantitative of IgG antibodies according to the method described by (Tary-Lehmann et al., 1998) with some modifications. Briefly, the 96well plates coated with inactivated purified BHV-1 antigen were incubated with diluted tested serum samples (1:100) were added wells and positive and negative control were included. Horseradish peroxidase-conjugated anti-rabbit IgG antibody at 1:200 dilution and incubated for one $\mathrm{h}$ at $37^{\circ} \mathrm{C}$. OPD substrate incubated for $10 \mathrm{~min}$ in the dark at $20^{\circ} \mathrm{C}$. The enzyme reaction was stopped by adding $100 \mu \mathrm{L}$ of $1.25 \mathrm{~mol} / \mathrm{L}$ H2SO4 per well and levels were read spectrophotometrically at $450 \mathrm{~nm}$.

\section{Cellular immune response}

The blood samples were collected in sterile heparinized tubes from five groups at the 3h, 6h, $12 \mathrm{~h}, 1$ day 2, 3, 4 and 5 days after inoculation. Blood was used for separation of mononuclear leukocytes for the lymphocyte proliferation assay to measure the cellular immune response of rabbits against BHV-1 assayed for cytokines such as TNF-a, IFN-g and IL2 by Enzyme-linked immunosorbent assay. Briefly, a 96-well flat bottom was coated with capture antibody specific to each cytokine. The plate was washed and blocked and serially diluted specific standards were added to the 
respective wells. Following a series of washing, the captured cytokine was detected using the specific conjugated detection antibody. The chromogen/substrate reagent was added into each well, and after color development, the plate was read at $450 \mathrm{~nm}$ using an ELISA reader.

\section{Re-isolation}

After treatment with propolis and green tea plant extract, samples were taken from nasal and conjunctival exudates, using a sterile cotton swab. The swab was transported to the laboratory in plastic vials with one mL of the transport medium (MEM serum-free medium supplemented with penicillin streptomycin-amphotericin $(10000 \mathrm{U} / \mathrm{mL}-10 \mu \mathrm{g} / \mathrm{mL}-$ $0.25 \mu \mathrm{g} / \mathrm{mL}$ ) and frozen at $-70{ }^{\circ} \mathrm{C}$. Swabs were washed in medium, and then centrifuged for $20 \mathrm{~min}$ at $1500 \mathrm{rpm}$ and the supernatant was filtered through a $0.45 \mu \mathrm{m}$ membrane. Tenfold dilutions of the filtrate were then put in contact with MDBK cell monolayers previously cultured in 96-well plates to isolate and titrate the virus according to (Chothe et al., 2018; Valera et al., 2008).

\section{Extraction of viral DNA}

DNA was extracted using the commercially available DNA extraction kit (Qiagen, USA), as indicated in the manufacturer's protocol. DNA extraction from the samples was extracted from harvested homogenate CAM with clear pock lesion and from supernatant culture of MDBK cell DNA was isolated using QIAamp DNA Mini Kit (Qiagen Ltd, USA). The DNA concentration and purification was measured using spectrophotometer and final elution of DNA was done in $50 \mathrm{uL}$ of elution buffer and stored at -20 for long term use.

\section{Polymerase chain reaction}

PCR specific primers of BHV-1 were used glycoprotein B $(\mathrm{gB})$ gene as target gene as protocol using by (Burleson et al., 1992; Suchard et al., 2012). To amplify the target sequence primers for BHV-1 glycoprotein B (gB) primers were (F, 5'-TGT GGA CCT AAA CCT CAC GGT-3'; R 5'- GTA GTC GACAG ACC CGT GTC- 3'), 1 l (25 pmol) of each primers, $5 \mu \mathrm{l}$ of the extracted DNA was added to $45 \mu \mathrm{l}$ of PCR mix containing $2.5 \mathrm{U}$ of Taq DNA polymerase, $5 \mu \mathrm{L}$ of 10X PCR buffer, $1.5 \mu \mathrm{l}$ of $50 \mathrm{mM} \mathrm{MgCl} 2,1 \mu \mathrm{l}$ of $10 \mathrm{mM}$ of dNTPs mix, The reaction was run under the following thermal cycling program: Pre-denaturing at $94^{\circ} \mathrm{C} / 3 \mathrm{~min}$; denaturing at $94^{\circ} \mathrm{C} / 1 \mathrm{~min}$, annealing at $60^{\circ} \mathrm{C} / 1 \mathrm{~min}$, extension at $72^{\circ} \mathrm{C} / 1 \mathrm{~min}$ repeated (35 cycles) followed by a final extension at $72^{\circ} \mathrm{C}$ for five min. Negative and positive control reactions were used. Agarose gel was performed according to (Sambrook et al., 1989). The DNA products were shown under Ultraviolet (UV) light of the PCR products in a $2 \%$ agarose with ethidium bromide $(0.3 \mathrm{mg} / \mathrm{ml})$ and used ladder $100 \mathrm{bp}$ molecular weight markers.

\section{Pathological studies}

Tissue specimens were collected immediately from liver, kidney and spleen after euthanized of animal groups at the end of experiment then fixed in $10 \%$ formal saline. Dehydrated, cleared and embedded in paraffin blocks were done. Paraffin sections of $5 \mu$ thickness were prepared, stained by H\&E and examined microscopically for detection of histopathological alterations.

\section{Statistical analysis}

Antibody titers were compared using statistical analysis by SPSS software version 16. The data obtained in this study were analyzed using One-way ANOVA of the GenStat Release 12 Edition. Significant differences were determined by analysis of variance (ANOVA) and significant level at $95 \%(\mathrm{P}<0.05)$ was determined

\section{RESULTS}

In vitro, cytotoxicity effect of water green tea extract, ethanol propolis extract and ACV on cultured MDBK at concentrations of $7.8-125 \mu \mathrm{g} \mathrm{mL}^{-1}$ caused cell cytotoxic by different degree were cell rounding and clumping that could be considered toxic effect on cell cultures ranged from 30 to $80 \%$ at levels $\geq 62.5 \mu \mathrm{g} \mathrm{mL}^{-1}$ on MDBK as in figure 1 . The cytotoxicity test was performed on MDBK cells. The values of CC50 of water green tea, ethanol propolis extracts are expressed in $\mu \mathrm{g} / \mathrm{ml}$. Overall, the water green tea, ethanol propolis extracts showed nearly similar CC50 values, varying between 7.8 and $125 \mu \mathrm{g} / \mathrm{ml}$ indicating that the toxicity of water green tea, ethanol propolis extracts are considered low at $50 \mu \mathrm{g} / \mathrm{ml}$ (Figure 1).

The ranges of antiviral effects of water green tea extract (WGE), Ethanol propolis extract (EPE) and ACV at concentrations on BHV-1 infected Madin-Darby Bovine Kidney (MDBK) cells culture. In vitro results showed the 50 ug $\mathrm{ml}^{-1}$ concentrations from different extracts and ACV inhibited BHV-1 at 90 to $100 \%$. However, Cytopatheic Effects (CPE) value reached 85 to $90 \%$ in infected cell with BHV-1 as in figure 2. In vivo, experiment all rabbits were inoculated with BHV-1 and treated with propolis extract, green tea extract and ACV drug for seven days post 
inoculation as in groups 12 and 3 revealed mild clinical signs than the $4^{\text {th }}$ group inoculated with BHV-1 was showed sever clinical signs included depression, salivation, nasal discharge, rules, and convulsions. There were no deaths or clinical signs were observed in the non-infected control negative group 5. Rabbit's body temperatures in the negative control group were normal until the end of the experiment. The commercially antiviral drug ACV group showed raised body temperature peak on day three post-treatment $\left(39.8^{\circ} \mathrm{C} \pm 0.566\right)$. The first group inoculated with BHV -1 and treated with propolis extract showed decreased body temperature $\left(38.9^{\circ} \mathrm{C} \pm 0.456\right)$, but the lower temperature on day two postinfection to $(38.3 \pm 0.325)$ as shown in figure 3 . The clinical signs, body temperature, nasal and ocular discharge in all groups post-infected with virulent BHV-1 mild to moderate, body temperature change in groups 1, 2, and 3 with mild clinical signs after challenge. Control negative group inoculated with Phosphate-Buffered Saline (PBS) showed normal healthy rabbits. While the Group 4 rabbits were inoculated BHV-1 showed high body temperature and sever respiratory signs with nasal ocular discharge as shown in figure 3.

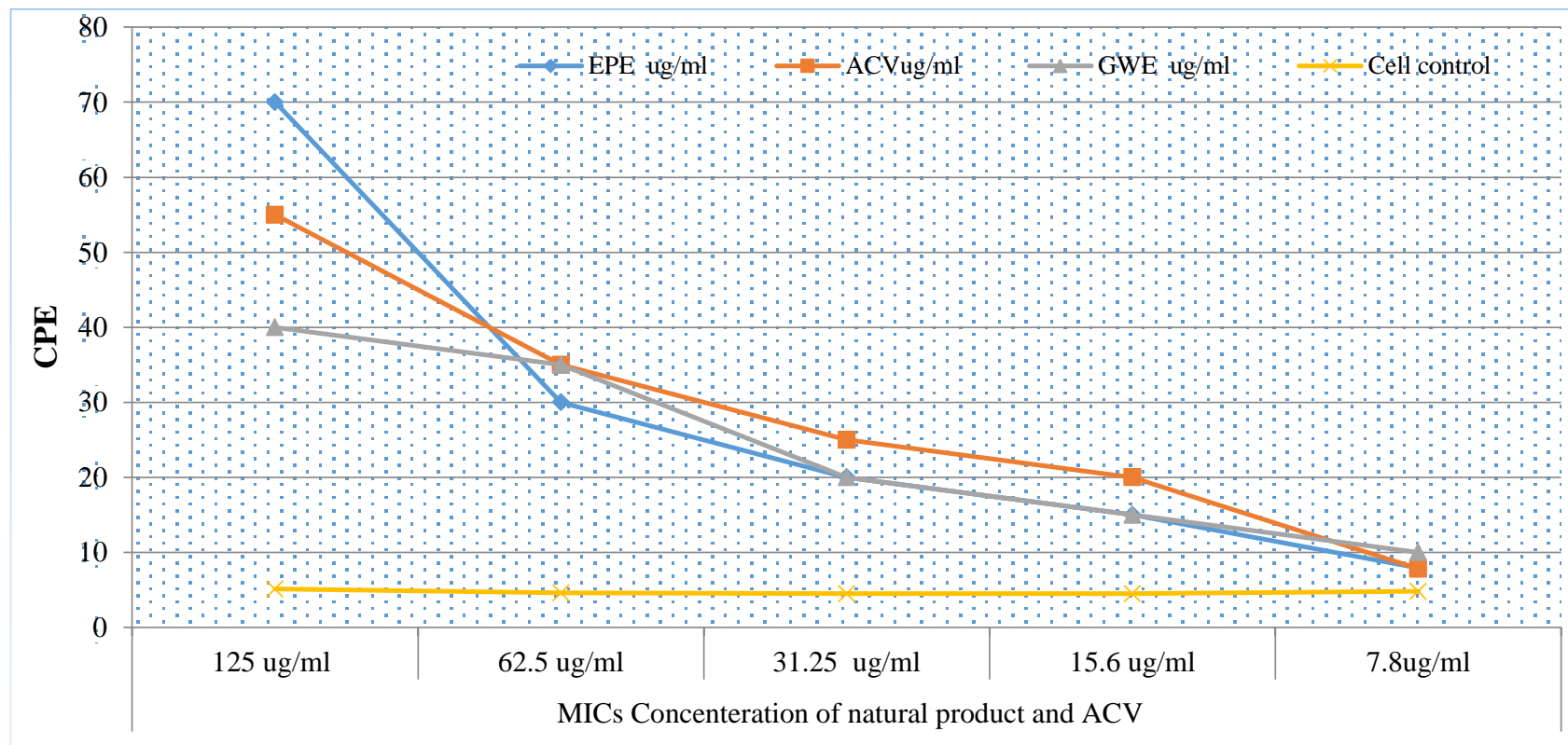

Figure 1. The Cytotoxic Concentration $\left(\mathrm{CC}_{50}\right)$ of water green tea, ethanol propolis extracts and ACV on Madin-Darby Bovine Kidney cell line. WGE: Water Green Tea Extract, EPE: Ethanol Propolis Extract, ACV: Acyclovir, MDBK: Madin-Darby Bovine Kidney cells

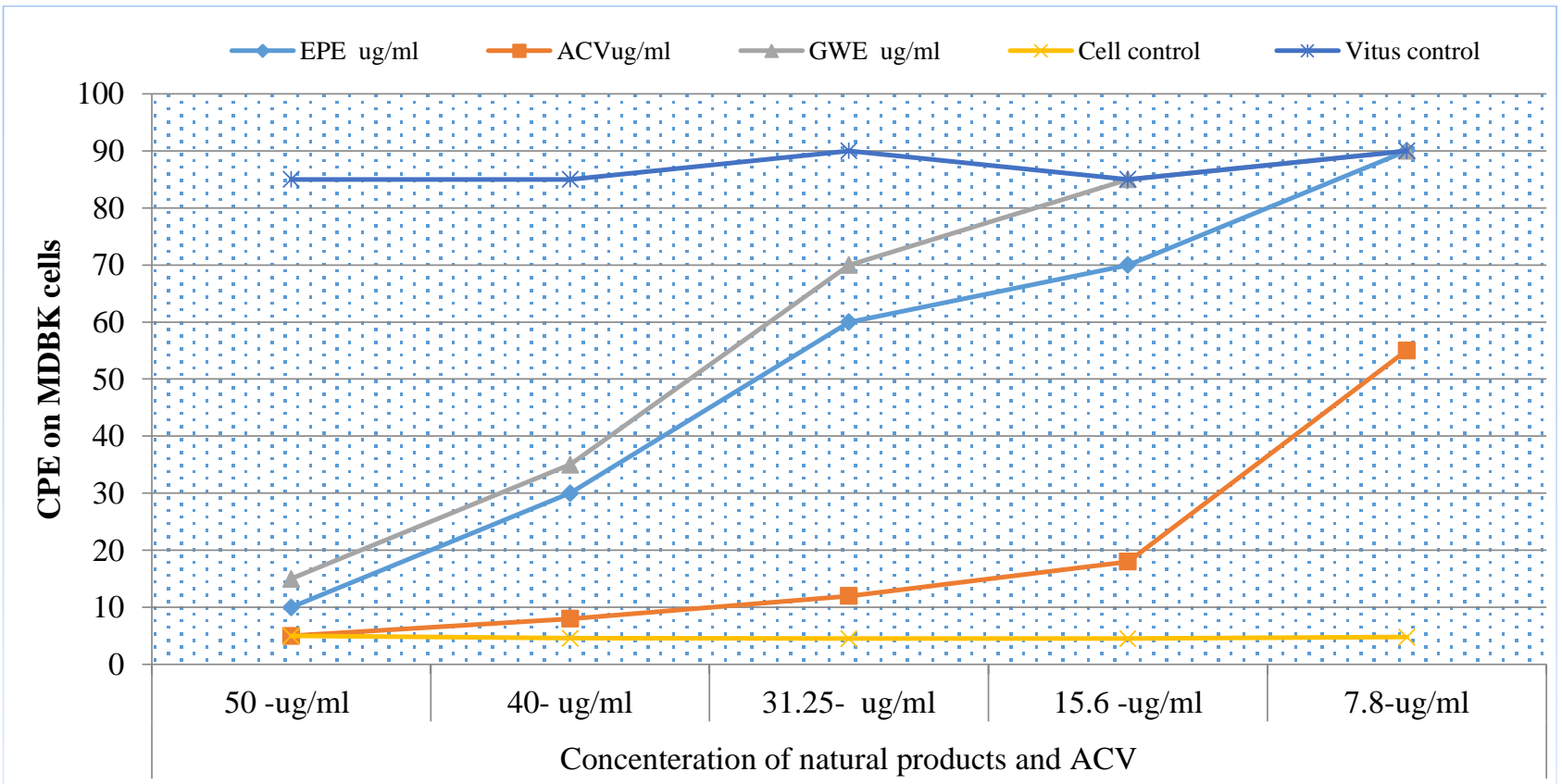

Figure 2. Inhibatory effects of green tea and propolis extracts on BHV-1 propagated in Madin-Darby Bovine Kidney cell line. WGE: Water Green Tea Extract, EPE: Ethanol Propolis Extract, ACV: Acyclovir, MDB: Madin-Darby Bovine Kidney cells 


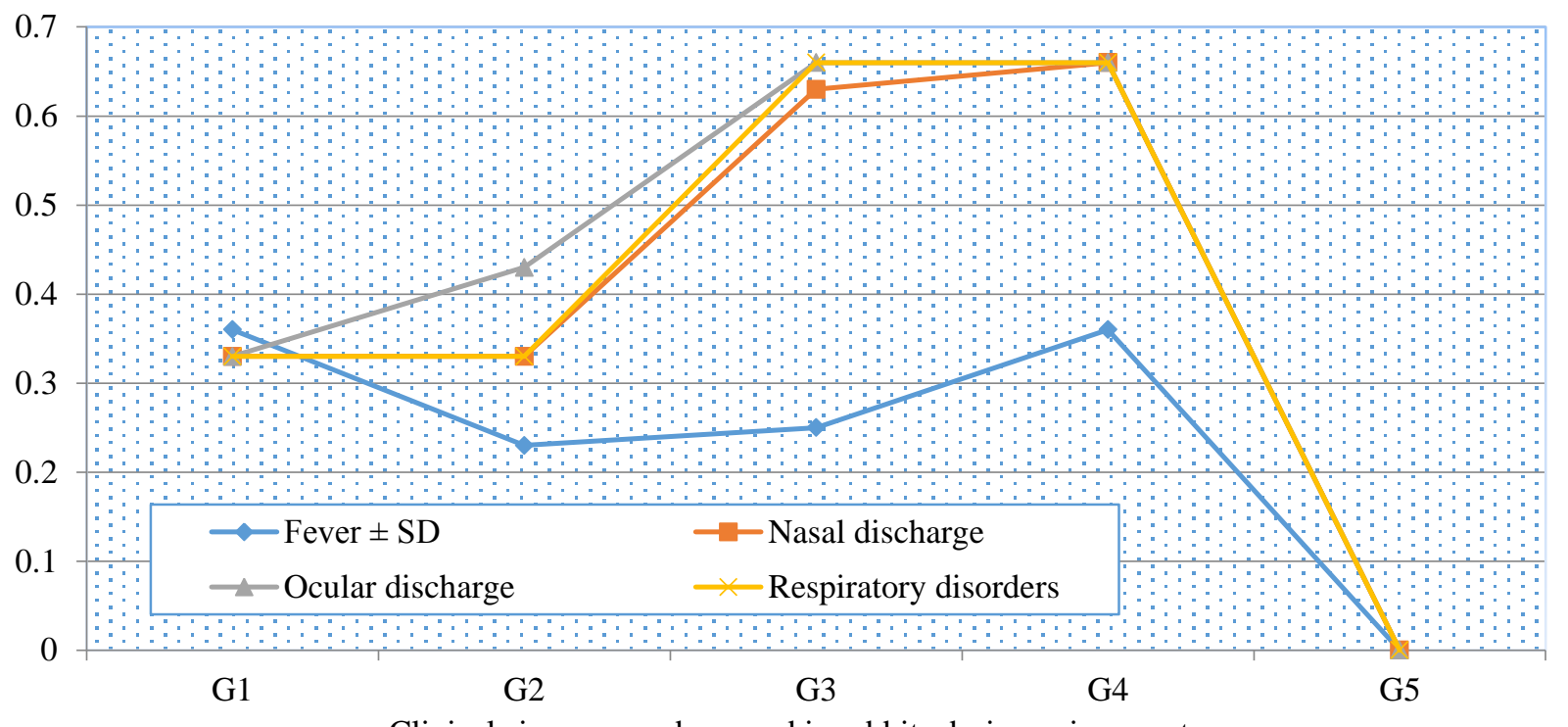

Clinical signs were obsevered in rabbits during exiperment

Figure 3. Different clinical signs in rabbits experiential infected with bovine herpes virus -1 and treated with propolis extract, green tea extract and Acylovir drug

\section{In vivo experiment}

Administration of propolis and green tea extracts for seven days post inoculation resulted increase IL-2, IFN- $\gamma$ and IFN-g cytokines respectively in propolis and green tea extracts treated rabbits at the seventh day from extracts administration in comparison to the control non-treated group negative group. marked increase in the levels of cytokines IL-2, and IFN- $\gamma$ in serum and cellular levels of all BHV-1-infected groups either propolis treated (group 1) and green tea treated (group 2) or untreated group (group 5). No differences were observed between the first and the second groups in cytokines levels. The re-isolated virus in rabbit's excretion failed re-isolated BHV-1 from extract and ACV treated groups compared to control positive and negative as shown in figure 4. Results in figure (4A, B and C) showed decreased in levels of IL-2, IFN, and IFN- $\gamma$ in BHV-1-infected group compared with postinfection treated groups 1 and 2 with the propolis and green tea extracts significant at $\mathrm{P} \leq 0.05$ observed between propolis and green tea extracts. The increased 10-20 fold in levels of IL-2, IFN and IFN- $\gamma$ cytokines respectively comparison to the control negative group 5 from $2^{\text {nd }}$ dpi to $5^{\text {th }}$ dpi as shown in figure 4 .
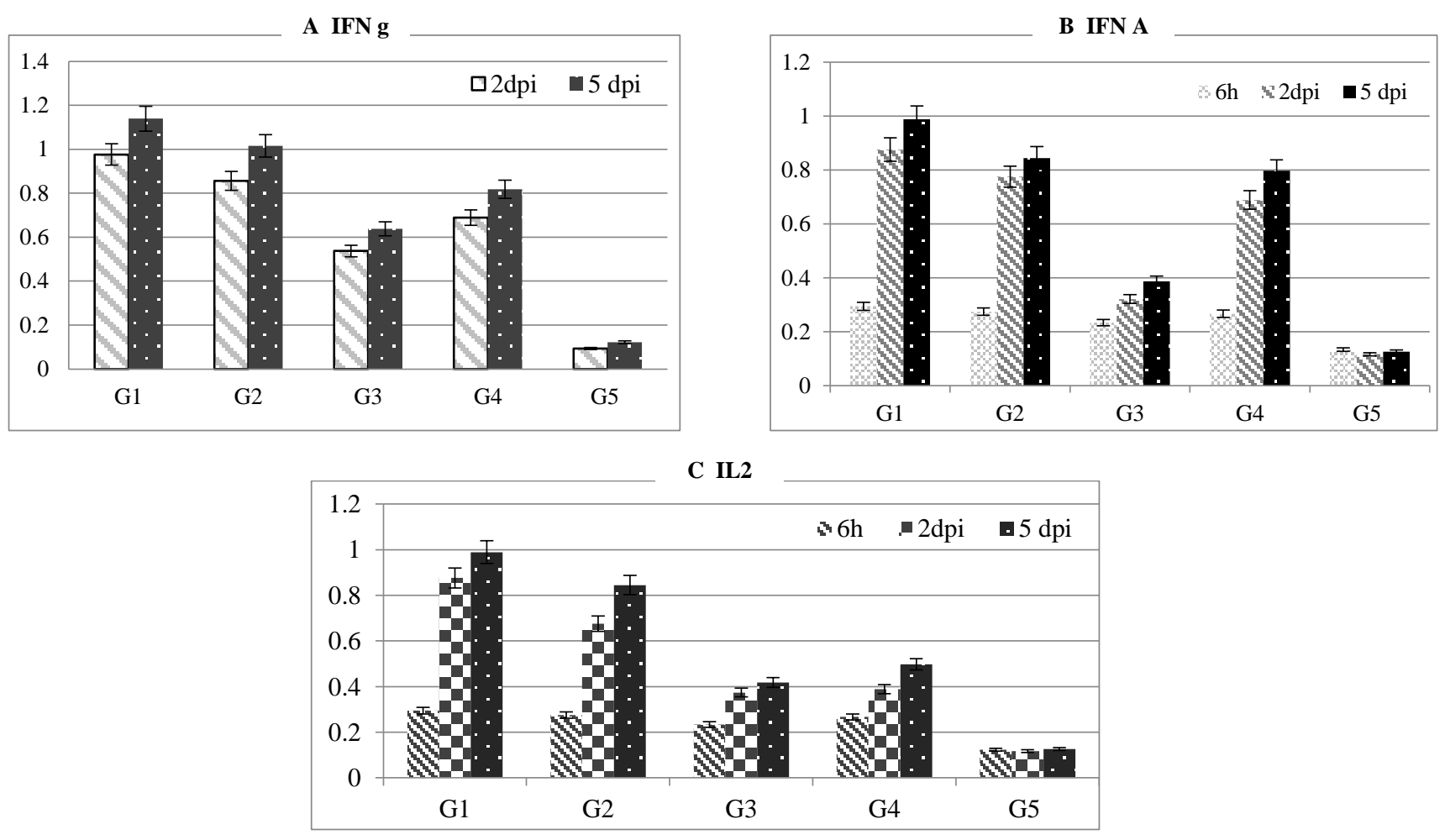

Figure 4. Effect of propolis and green tea extracts post infected treatment for seven days on cytokines production in experimentally infected rabbits with BHV-1. 


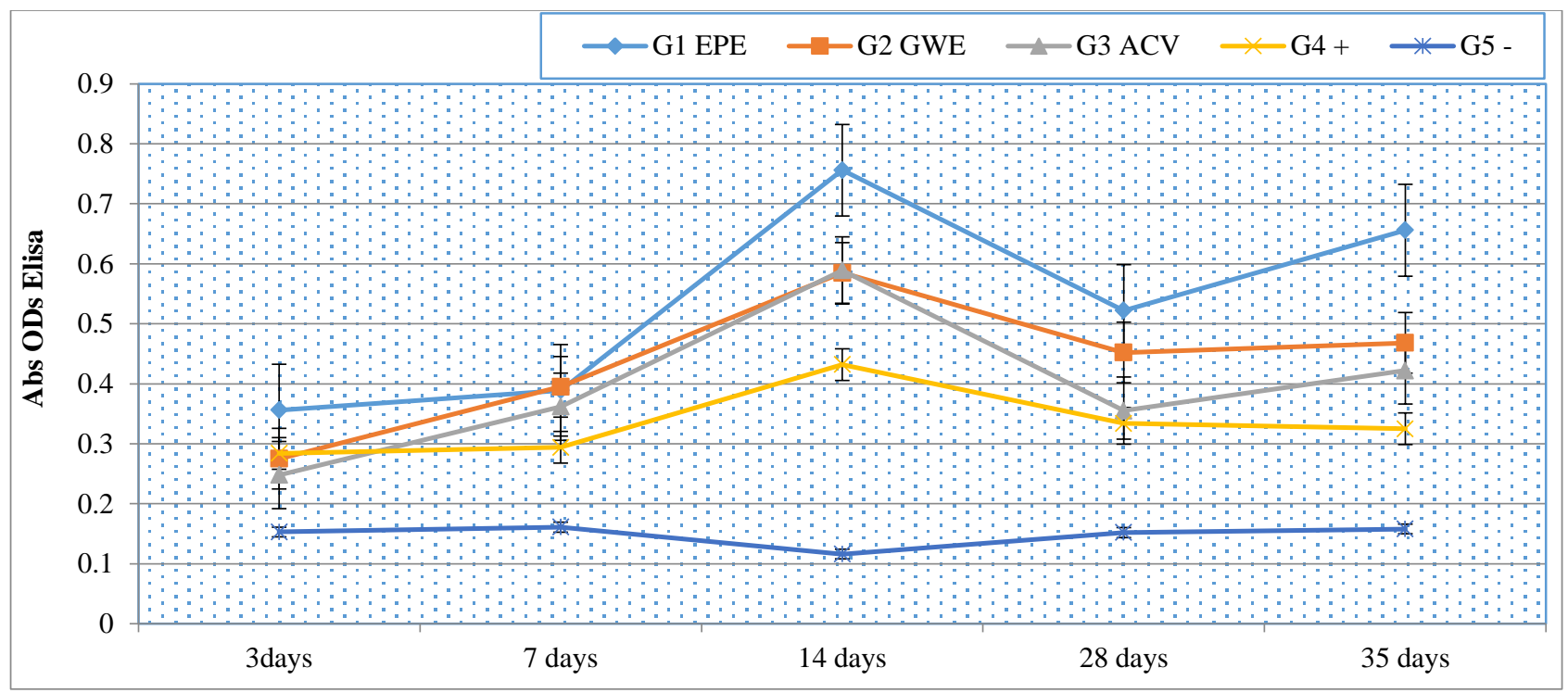

Figure 5. Effect of Green tea, propolis extracts and Acyclovir on antibody production in rabbits inoculated with BHV1. T: Significant between groups at $\mathrm{t}<0.05$ using CI $=95 \%$. Different letters in the same row means significant changes at $\mathrm{t}<0.05$. ** Highly significant at $\mathrm{t}<0.01$ by using CI $=99 \%$ WGE: Water Green Tea Extract, EPE: Ethanol Propolis Extract, ACV: Acyclovir, MDBK: Madin-Darby Bovine Kidney cells
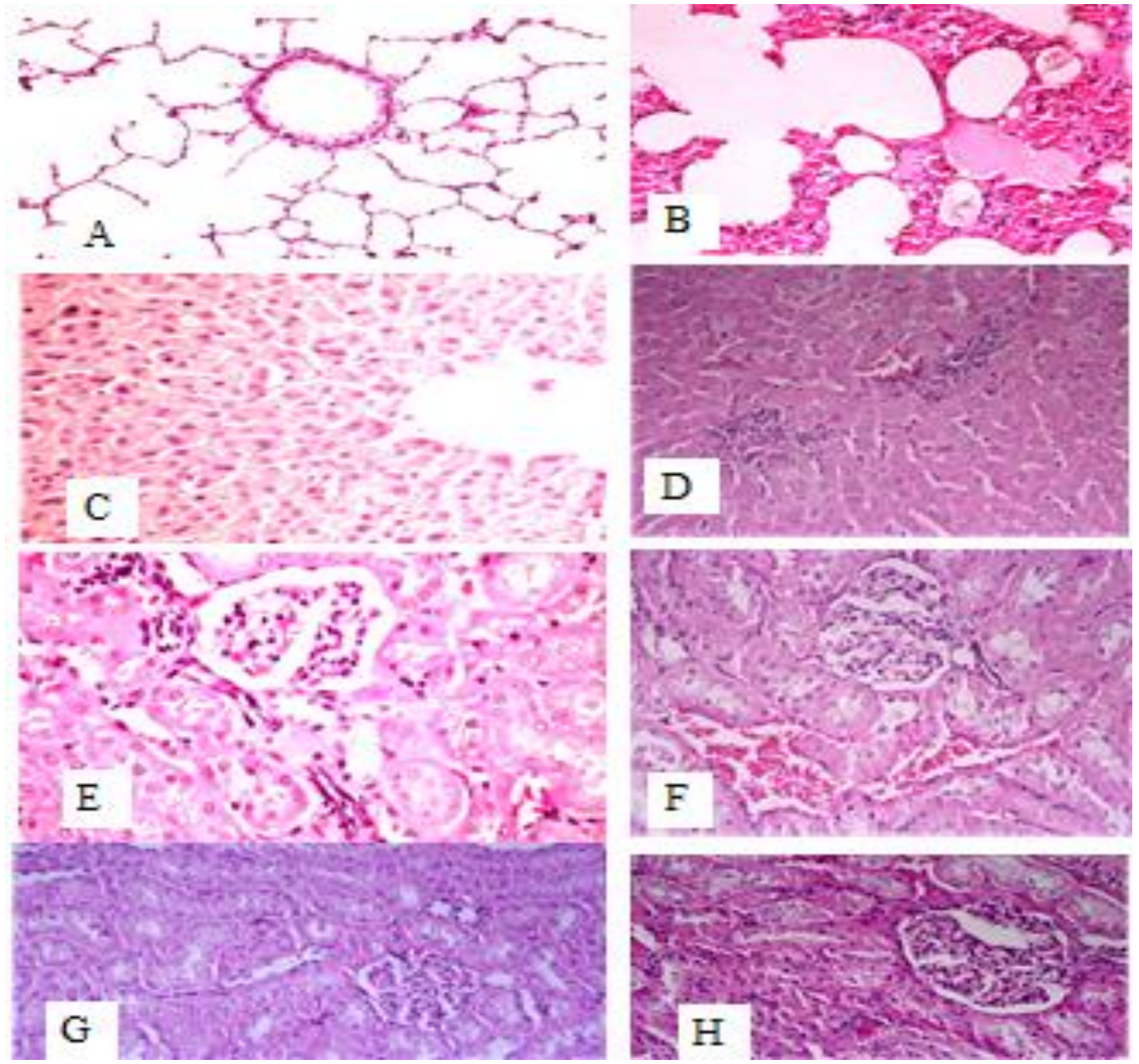

Figure 6. Histopathological finding in lung, liver, and kidney of experimentally infected rabbit with bovine herpes virus -1

To cite this paper: Zeedan GSG, Abd El-Razik KhAE-H, Abdel-Shafy S, Farag TK and Mahmoud AH (2019). The Effects of Green Tea and Propolis Extracts on proinflammatory cytokines TNF- $\alpha$, IFN- $\gamma$, IL2, and Immunoglobulin Production in Experimentally Infected Rabbits with Bovine Herpesvirus-1. World Vet. J., 9 (4): $329-339$. http://wvj.science-line.com 
The antiviral drug ACV induces antibody titer against BHV-1 lower than group of rabbits inoculated with BHV-1 were treated with propolis and green tea extracts. All rabbits had no antibodies against BHV-1 at zero day before inoculation. All control negative groups remained seronegative during this time (Figure 5).

The non-infected control negative group received Phosphate-Buffered Saline (PBS) showed no histopathological changes in the lung, liver, and kidney as shown in figure 5A, C, and G respectively. Histopathological changes in rabbit's organs receive the extracts post experiment infection with BHA-1, showed mild histopathological changes in the lung, liver, and kidney Lung, but in infected group inoculated with BHV-1 without treated with extracts or ACV showed sever congestion, and inflammatory reaction pulmonary edema, hemorrhage and hemosiderosis, liver showed hepatitis, leucocytic inflammatory cells and megakaryocytes in the hepatic sinusoids as well as apoptosis of hepatocytes, Kidney showed hypertrophy and hypercellularity of glomerular tuft as well as vacuolation of endothelial lining glomerular as shown in figure $5 \mathrm{~B}, \mathrm{D}, \mathrm{F}$ and $\mathrm{H}$ (H\&E, x200).

\section{DISCUSSION}

BHV-1 is a worldwide contagious disease of socioeconomic importance. In Egypt, BHV-1 has been reported in many provinces up-to-date. Therefore there is a need to continue research to control BHV-1. BHV-1 uses a variety of mechanisms to elude the host's immune system, by spreading intracellularly; it can exist in the presence of virus specific antibodies (Ferrari et al., 2006). Furthermore, cell-mediated immune responses depressed as a result of BHV-1 infection (Tardif et al., 2014).

It is a fact that the BHV-1 vaccination is the most efficient method to control and eradicates the disease in country with high seroprevalence. according to (Raaperi et al., 2014). But the risk of reversion to virulence, induction of latency of the vaccine strain and the inability to apply them to pregnant cows, due to the risk of inducing abortion (Jones and Chowdhury, 2010). Although there are antiviral drugs available for the treatment of herpes viruses. It is also reported that there is serious viral resistance to existing antiviral drugs (Wang et al., 2015).

Increasing drug resistance in these infections stimulates the search for drugs that are more potent and easily accessible. Recently, purified natural products and herbal medicines provide a rich resource for novel antiviral drug development (OIE, 2008; Romera et al., 2014 ), such as propolis is a natural product safe for human and animal, it has been approved as health food or medicine in many countries (Baylor et al., 2002; Sforcin, 2007; Sivakumar et al., 2011). Also, green tea had virucidal effect on BHV-1 (Hsieh et al., 2014).

The present study evaluated antiviral activities of water green tea extract, and Ethanol propolis extract against BHV-1 virus comparing to commercial ACV drug in vitro and in vivo. The cytotoxicity of water green tea extract, and Ethanol propolis extracts on MDBK at high concentration $125 \mathrm{ug} \mathrm{ml}^{-1}$, while they had low or absent of cytotoxic effect at 7.8 to $50 \mu \mathrm{g} \mathrm{mL}^{-1}$ or below means that's extracts were considerable as a relatively toxic in figure 1 and this results was regarding with (Hegazi et al., 2001; Zeedan et al., 2014; Isidorov et al., 2016).

The antiviral activity of propolis and green tea extracts on BHV-1 infected MDBK cells produced higher inhibitory effects on BHV-1 than ACV. The antiviral activity of propolis and green tea had stronger effect on BHV-1 might be due to a major components of extracts that interfere in the replication by inhibiting protein synthesis. In addition, some components have been reported to inhibit the enzymatic activity, viral attachment and penetration as shown in figure 2 shown, the results according with Kwak et al. (2004) and Kaihatsu et al. (2018) who suggested that epigallocatechin gallate (EGCG) (the primary catechin in green tea) used in potent and universal virus inhibitor among the natural catechins, directly interacting not only with various types of enveloped DNA, (+)-RNA, and (-)-RNA viruses, but also various types of cells. However, the propolis could be inhibit virus propagation through reduction of viral multiplication and induced virucidal action (De Koeijer et al., 2008; Superti et al., 2008). The present work was aimed to evaluate antiviral effect of ethanol of propolis and green tea extracts on BHV-1 infected rabbits. Propolis and green tea were administrated either orally and by S/C injection at $7 \mathrm{dpi}$. In order assess the potential of this activities as a tool for BHV by PCR and trials for re-isolated applied to show that couldn't detect BHV-1 infected MDBK cells from nasal samples were collected from treated groups by extracts 7dpi. In contrast, the PCR products have weak yields or gave a negative result for treated groups with propolis and green tea extracts. The density and characters of clinical signs between the control positive group which was infected with BHV-1 without treatment with extracts or drug as in figure 3 . The highest potency of pro-inflammatory cytokines IL-2 and IFN- $\gamma$ in sera of rabbits treated with propolis and green tea extracts at 7dpi. Th-1 cytokines, IL-2 and IFN- $\gamma$ increased in propolis and green tea extracts -treated groups in comparison to those of the control group. IL-2, a cytokine secreted by type 1 helper T cells (Th1 cells), mediates cellular immunity. In addition, IL-2 can stimulate the production of immunoglobulins and promote the proliferation as in figure 4, differentiation of natural killer cells and protection rabbits against BHV-1 and decreasing shedding of virus (Mahan et al., 2016). The antiviral property of polyphenols is due to their antioxidants nature, inhibition of the enzymes involved in viral replication and to their cell membrane disruption. First, the dimeric molecules, such as theaflavin and procyanidin B-2, generally displayed more potent antiviral activity against both influenza A and B viruses than the 
catechin monomers. Second, the kaempferol for inhibition of influenza B virus indicated that the more planar flavonol structure with only one $\mathrm{C}-4^{\prime}$ phenolic hydroxyl group in the B ring is necessary for the anti-influenza B virus activity. The green tea polyphenols also blocked viral penetration and binding to cells triggering the self-defense of the host cell influencing the activity of a variety of signal transduction pathways (Narotzki et al., 2012; Waters et al., 2016; Dhakal et al., 2018).

The antiviral drug ACV induces antibody titer against BHV-1 lower than group of rabbits inoculated with BHV-1 were treated with propolis and green tea extracts. All rabbits had no antibodies against BHV-1 at zero day before inoculation. All control negative groups remained seronegative during this time as in figure 5 .

Present results were confirmed by histopathological examination of rabbit's lung, liver and kidney specimens collected from all scarified rabbit groups. Group 4 showed sever multiple focal areas of coagulative necrosis. While, the liver of treated rabbits at 7 dpi in groups 1,2 and 3 have less severe or mild lesion represented by mononuclear cell infiltration in the portal areas and normal hepatocytes with mild portal congestion respectively as in figure 6 . These results were in consistent with (Hashimoto et al., 2015). Finally, propolis and green tea extracts have been proved to be effective against BHV-1 infection in vitro or in vivo, and stimulated production of cytokines and antibody against BHV-1 in experimentally infected rabbits.

\section{CONCLUSION}

In vitro study the cytotoxicity of green tea and propolis extracts were found safe and have low cytopathic effects at dose ranged from 7.8 to $50 \mu \mathrm{g} \mathrm{mL}^{-1}$. The green tea and propolis extracts had inhibitory effect on BHV-1similar and had more viricidal effect than antiviral drug Acylovir. Propolis and green tea extracts at $50 \mathrm{ug} / \mathrm{ml}$ could stimulat both humoral and cellular immune responses as well as increased pro-inflammatory cytokines such as TNF-a, IFN-g and IL2. They able to protect experimentally infected rabbits against BHV-1. The green tea and propolis extracts considered important sources for the development of new antiviral agents as an alternative to commercial antivirals drug uses.

\section{DECLARATIONS}

\section{Competing interestes}

The authors declared that they have no competing interests.

\section{Author's contributions}

GSZ found research idea, planned the study design, performed data, performed the laboratory work PCR and drafted the manuscript. KAA and AMA shared in the research's idea, sharing shared designed work, and helped in drafting the manuscript. TKF shared in a collection of blood samples during in experiment and helped in manuscript preparation. SA interpreted the data results and helped in manuscript preparation. All authors read and approved the final manuscript

\section{REFERENCES}

Allison AC and Byars NE (1991). Immunological adjuvants: desirable properties and side-effects. Molecular Immunology, 28: 279-84. DOI: https://doi.org/10.1016/0161-5890(91)90074-T

Alm-Eldeen AA, Basyony MA, Elfiky N K and Ghalwash MM (2017). Effect of the Egyptian propolis on the hepatic antioxidant defense and proapoptotic p53 and anti-apoptotic bcl2 expressions in aflatoxin B1 treated male mice. Biomedicine and Pharmacotherapy, 87: 247-255. DOI:https://doi.org/10.1016/j.biopha.2016.12.084

Anita P, Sivasamy S, Kumar, PDM, Balan IN and Ethiraj S (2014). In vitro antibacterial activity of Camellia sinensis extract against cariogenic microorganisms. Journal of Basic and Clinical Pharmacy, 6: 35-39 DOI: https://10.4103/0976-0105.145777

Araghizadeh A, Kohanteb J and Fani MM (2013). Inhibitory activity of green tea (Camellia sinensis) extract on some clinically isolated cariogenic and periodontopathic bacteria. Journal of Basic and Clinical Pharmacy, 22: 368-372. DOI: https://doi.org/10.1159/000348299

Baylor NW, Egan W and Richman P (2002). Aluminum salts in vaccines--US perspective. Vaccine, 20: S18-S23. DOI: https://doi.org/10.1016/S0264-410X(02)00166-4

Biswas S, Bandyopadhyay S, Dimri UH and Patra P (2013). Bovine herpesvirus-1 (BHV-1)-a re-emerging concern in livestock: a revisit to its biology, epidemiology, diagnosis, and prophylaxis. Veterinary Quarterly, 33: 68-81 DOI: https://doi.org/10.1080/01652176.2013.799301

Burleson FG, Chambers TM and Wiedbrauk DL (1992) Virology: a laboratory manual. Elsevier .

Chothe SK, Sebastian A, Thomas A, Nissly RH, Wolfgang D, ByukusengeM, Mor SK, Goyal SM, Albert I, Tewari D et al. (2018). Whole-genome sequence analysis reveals unique SNP profiles to distinguish vaccine and wild-type strains of bovine herpesvirus-1 (BoHV-1). Virology 522: 2736. DOI: https://doi.org/10.1016/J.VIROL.2018.06.015

Chung YC, Shen HY, Cheng LT, Liu SS and Chu CY (2016). Effectiveness of a BHV-1/BEFV bivalent vaccine against bovine herpesvirus type 1 infection in cattle. Research in Veterinary Science, 109: 61-165. DOI:https://doi.org/10.1016/j.rvsc.2016.10.004

Civitelli L, Panella S, Marcocci ME, De Petris A, Garzoli S, Pepi F, Vavala E, Ragno R., Nencioni L, Palamara AT et al . (2014). In vitro inhibition of herpes simplex virus type 1 replication by Mentha suaveolens essential oil and its main component piperitenone oxide. Phytomedicine, 21: 857-865. DOI:https://doi.org/10.1016/j.phymed.2014.01.013 
Cragg GM and Newman DJ (2013). Natural products: a continuing source of novel drug leads. Biochimica et Biophysica Acta (BBA)-General Subjects, 1830: 3670-3695. DOI:https://doi.org/10.1016 /j.bbagen. 2013. 02.008

De Koeijer AA, Diekmann O and de Jong MCM (2008). Calculating the time to extinction of a reactivating virus, in particular bovine herpes virus. Mathematical Biosciences, 212: 111-131. DOI:https://doi.org/10.1016/j.mbs.2007.04.002

De Oliveira A, Prince D, Lo CY, Lee LH and Chu TC (2015). Antiviral activity of theaflavin digallate against herpes simplex virus type1. Antiviral research 118: 56-67. DOI:https://doi.org/10.1016/j.antiviral.2015.03.009

De Santana Aquino DF, Piccinell AC, Soares FLP, Arena AC, Salvador MJ and Kassuya CAL (2015). Anti-hyperalgesic and Anti-inflammatory Activity of Alternanthera Maritima Extract and 2"-O- $\alpha-1-r h a m n o p y r a n o s y l v i t e x i n$ in Mice. Inflammation, 38: 2057-2066. DOI:https://doi.org/10.1007/s10753-015-0187-0

Dhakal S, Renu S, Ghimire S, Shaan Lakshmanappa Y, Hogshea BT, Feliciano-Ruiz, N, Lu F, HogenEsch H, Krakowka S et al. (2018). Mucosal Immunity and Protective Efficacy of Intranasal Inactivated Influenza Vaccine Is Improved by Chitosan Nanoparticle Delivery in Pigs. Frontiers in immunology. DOI:https://doi.org/10.3389/fimmu.2018.00934

Diallo IS, Corney BG and Rodwell BJ (2011). Detection and differentiation of bovine herpesvirus 1 and 5 using a multiplex real-time polymerase chain reaction. Journal of Virological Methods, 175: 46-52. DOI:https://doi.org/10.1016/J.JVIROMET.2011.04.013

Drummond AJ, Suchard MA, Xie D and Rambaut A (2012). Bayesian phylogenetics with BEA Uti and the BEAST 17 Molecular Biology and Evolution, 29: 1969-1973. DOI: https://10.1093/molbev/mss075

Duhan V, Khairnar V, Friedrich S, Zhou F, Gassa A, Honke N, Shaabani N, Gailus N, Botezatu L Khandanpour K et al. (2016). Virus-specific antibodies allow viral replication in the marginal zone, thereby promoting CD8+T-cell priming and viral control. Scientific Report, 6: 19191. DOI: https://10.1038/srep19191

Gavanji S, Sayedipour SS, Larki B and Bakhtari A (2015). Antiviral activity of some plant oils against herpes simplex virus type 1 in Vero cell culture. Journal of Acute Medicine 5: 62-68. DOI:https://doi.org/10.1016/j.jacme.2015.07.001

Hashimot H, Kitano S, Yamagata S, Miyagi Maeshima A, Ueda R, Ito A, Tada K, Fuji S, Yamashita T, Tomura D, Nukaya I et al. (2015). Donor lymphocytes expressing the herpes simplex virus thymidine kinase suicide gene: detailed immunological function following add-back after haploidentical transplantation. Cytotherapy 17: 1820-1830. DOI:https://doi.org/10.1016/j.jcyt.2015.08.005

Hegazi AG, Farghaly AA and Abd El Hady FK (2004). Egyptian propolis: 5 influence of propolis adminestration on some chicken biochemical parameters. Journal of Applied Veterinary Science NRC, 1:43-58.

Hegazi AG, Farghaly AA and El Hady A (2001). Antiviral activity and chemical composition of European and Egyptian propolis. In Proceedings of the 37th International Apiculture Congress.

Hemmatzadeh F, Boardman W, Alinejad A, Hematzade A and Moghadam MK (2016). Molecular and serological survey of selected viruses in freeranging wild ruminants in Iran. PLoS One, 11 (12): e0168756. DOI: https://doi.org/10.1371/journal.pone.0168756

Hsieh JC, Kuta R, Armour CR and Boehmer PE (2014). Identification of two novel functional p53 responsive elements in the herpes simplex virus-1 genome. Virology, 460: 45-54. DOI: https://doi.org/10.1016/j.virol.2014.04.019

Isidorov V A, Bakier S, Pirożnikow E, Zambrzycka M and Swiecicka I (2016). Selective behaviour of honeybees in acquiring European propolis plant precursors. Journal of chemical ecology, 42:475-485. DOI: https://doi.org/10.1007/s1088

Jones C and Chowdhury S (2010). Bovine Herpesvirus Type 1 (BHV-1) is an Important Cofactor in the Bovine Respiratory Disease Complex. Veterinary Clinics Food Animals Practices, 26: 303-321. DOI: https://doi.org/10.1016/j.cvfa.2010.04.007

Kaihatsu K, Yamabe M and Ebara Y (2018) Antiviral Mechanism of Action of Epigallocatechin-3-O-gallate and Its Fatty Acid Esters. Molecules, 23:2475. DOI: https://10.3390/molecules23102475

Kook I, Henley C, Meyer F, Hoffmann FG and Jones C (2015). Bovine herpesvirus 1 productive infection and immediate early transcription unit 1 promoter are stimulated by the synthetic corticosteroid dexamethasone. Virology, 484: 377-385. DOI: https://doi.org/10.1016/j.virol.2015.06.010

Kuete V, Wiench B, Hegazy MEF, Mohamed TA, Fankam AG, Shahat AA and Efferth T (2012). Antibacterial activity and cytotoxicity of selected Egyptian medicinal plants. Planta Medica, 78: 193-199. DOI: https://10.1055/s-0031-1280319

Kwak H, Mustafa W, Speirs, K, Abdool AJ, Paterson Y and Isaacs SN (2004). Improved protection conferred by vaccination with a recombinant vaccinia virus that incorporates a foreign antigen into the extracellular enveloped virion. Virology, 322: 337-348. DOI:https://doi.org/10.1016/j.virol.2004.02.007

Lee M, Reed A, Estill C, Izume S, Dong J and Jin L (2015). Evaluation of BHV-1 antibody titer in a cattle herd against different BHV-1 strains. Veterinery Microbiology, 179: 228-232. DOI:https://doi.org/10.1016/j.vetmic.2015.06.009

Lirdprapamongkol K, Sakurai H, Abdelhamed S, Yokoyama S, Athikomkulchai S., Viriyaroj A, Awale, S, Ruchirawa S, Svast J and Saiki I (2013). Chrysin overcomes TRAIL resistance of cancer cells through Mcl-1 downregulation by inhibiting STAT3 phosphorylation. International Journal of Oncology, 43: 329-337. DOI:https://doi.org/10.3892/ijo.2013.1926

Mahan SM, Sobecki B, Johnson J, Oien NL, Meinert T, Verhelle S, Mattern SJ, Bowersock TL, Leyh and RD (2016). Efficacy of intranasa vaccination with a multivalent vaccine containing temperature-sensitive modified-live bovine herpesvirus type 1 for protection of seronegative and seropositive calves against respiratory disease. Journal of the American Veterinary Medical Association, 248: 1280-1286. DOI: https://doi.org/10.2460/javma.248.11.1280

Matsusaki T, Takeda S, Takeshita M, Arima Y, Tsend-Ayush C, Oyunsuren T, Sugita C, Yoshida H, Watanabe W and Kurokawa M (2016). Augmentation of $\mathrm{T}$ helper type 1 immune response through intestinal immunity in murine cutaneous herpes simplex virus type 1 infection by probiotic Lactobacillus plantarum strain 06CC2. International Immunopharmacol. 39: 320-327. DOI:https://doi.org/10.1016/j.intimp.2016.08.001

Münstedt K (2019). Comment" Topical application of honey in the management of chemo/radiotherapy-induced oral mucositis: A systematic review and network meta-analysis."(Yang et al.(2019)). International journal of nursing studies, 92:57- 92. DOI:https://doi.org/10.1016/j.ijnurstu.2019.01.005

Muylkens B, Thiry J, Kirten P, Schynts F and Thiry E (2007). Bovine herpesvirus 1 infection and infectious bovine rhinotracheitis. Veterinary research, 38:181-209. DOI: https://doi.org/10.1051/vetres:2006059

Narotzki B, Reznick A Z, Aizenbud D and Levy Y (2012). Green tea: a promising natural product in oral health. Archives of oral biology, 57: 429435. DOI: https://doi.org/10.1016/j.archoralbio.2011.11.017

Office international des épizooties (OIE) (2008). Biological Standards Commission and International Office of Epizootics. Manual of diagnostic tests and vaccines for terrestrial animals: mammals, birds and bees (Vol. 2).

Office international des épizooties (OIE) (2018) Manual of Diagnostic Tests and Vaccines for Terrestrial Animals, Office International des Epizooties. World Organization for Animal Health, Paris, France

Pande H, Riggs AD, Zaia JA and Clark BR (2001). U.S. Patent No. 6,242,567. Washington, DC: U.S.. Patent and Trademark Office.

To cite this paper: Zeedan GSG, Abd El-Razik KhAE-H, Abdel-Shafy S, Farag TK and Mahmoud AH (2019). The Effects of Green Tea and Propolis Extracts on proinflammatory cytokines TNF- $\alpha$, IFN- $\gamma$, IL2, and Immunoglobulin Production in Experimentally Infected Rabbits with Bovine Herpesvirus-1. World Vet. J., 9 (4): 329-339. http://wvj.science-line.com 
Paulino de Souza J, Dias do Prado C, Eleutherio ECA, Bonatto D, Malavazi I and Ferreira da Cunha A (2018). Improvement of Brazilian bioethanol production - Challenges and perspectives on the identification and genetic modification of new strains of Saccharomyces cerevisiae yeasts isolated during ethanol process. Fungal Biolology, 122: 583-591. DOI: https://10.1016/j.funbio.2017.12.006

Raaperi K, Orro T and Viltrop A (2014) Epidemiology and control of bovine herpesvirus 1 infection in Europe. The Veterinary Journal, 201: 249256. DOI:https://doi.org/10.1016/j.tvj1.2014.05.040

Research NRC (1996). Guide for the Care and Use of Laboratory Animals, Guide for the Care and Use of Laboratory Animals. National Academies Press (US). DOI:https://doi.org/10.17226/5140

Romera SA, Puntel M, Quattrocchi V, Del Médico Zajac P, Zamorano P, Blanco Viera J, Carrillo C, Chowdhury S, Borca MV et al. (2014). Protection induced by a glycoprotein E-deleted bovine herpesvirus type 1 marker strain used either as an inactivated or live attenuated vaccine in cattle. BMC veterinary research, 10:8-20. DOI:https://doi.org/10.1186/1746-6148-10-8

Sambrook J, Fritsch, EF and Maniatis T (1989). Molecular cloning: a laboratory manual. Cold spring harbor laboratory Transplantation Osteoporosis 8: 364-368.

Schuppers ME, Stegeman JA, Kramps JA and Stärk KDC(2012). Implementing a probabilistic definition of freedom from infection to facilitate trade of livestock: Putting theory into praxis for the example of bovine herpes virus-1. Preventive veterinary medicine, 105:195-201. DOI:https://doi.org/10.1016/j.prevetmed.2011.12.013

Sforcin JM (2007). Propolis and the immune system: a review. Journal of Ethnopharmacology, 113:1-14. DOI: https://doi.org/10.1016/j.jep.2007.05.012

Sivakumar SM, Safhi MM, Kannadasan M and Sukumaran N( 2011). Vaccine adjuvants - Current status and prospects on controlled release adjuvancity. Saudi pharmaceutical society, 19: 197-206. DOI: https://doi.org/10.1016/j.jsps.2011.06.003

Soós Á, Bódi É, Várallyay S, Molnár S and Kovács B (2019). Mineral content of propolis tinctures in relation to the extraction time and the ethanol content of the extraction solvent. LWT - Food Science and Technology, 111(20): 719-726. DOI: https://doi.org/10.1016/j.lwt.2019.05.090

Superti F, Ammendolia MG and Marchetti M (2008). New advances in anti-HSV chemotherapy. Current medicinal chemistry, 15 : $900-911$.

Tardif KD, Jorgensen S, Langer J, Prichard M and Schlaberg R (2014). Simultaneous titration and phenotypic antiviral drug susceptibility testing for herpes simplex virus 1 and 2. Journal of Clinical Virology, 61:382-386. DOI:https://doi.org/10.1016/j.jcv.2014.08.015

Tary-Lehmann M, Hricik DE, Justice AC, Potter NS, and Heeger PS (1998). Enzyme -Linked Immunosorbent Assay Spot Detection of Interferon and Interleukin 5-Producing Cells as Readictive marker for Renal Allograft Failurei. Transplantation 66: $219-224$.

Thakur V, Kumar M and Rathish RL (2017). Seroprevalence of bovine herpesvirus-1 antibodies in bovines in five districts of Uttarakhand. Veterinary world, 10(1): 140-143. DOI: https://10.14202/vetworld.2017.140-143

Valera AR, Pidone CL, Massone AR, Quiroga MA, Riganti JG, Corva SG and Galosi CM (2008). A simple method of infecting rabbits with Bovine herpesvirus 1 and 5. Journal of Virological Methods 150: 77-79. DOI:https://doi.org/10.1016/j.jviromet.2008.03.008

Vlietinck AJ, Berghe DA and Vanden A (1991). Can ethnopharmacology contribute to the development of antiviral drugs?. Journal Ethnopharmacology, 32: 141-153. DOI:https://doi.org/10.1016/0378-8741(91)90112-

Vu HA, Beppu Y, Chi HT, Sasaki K, Yamamoto H, Xinh PT, Tanii T, Hara Y, Watanabe T, Sato Y et al. (2011). Green tea epigallocatechin gallate exhibits anticancer effect in human pancreatic carcinoma cells via the inhibition of both focal adhesion kinase and insulin-like growth factor-I receptor. Biomedical Biotechnology, pp. 20-10. DOI: https://10.1155/2010/290516

Wang, J, Guo X, Yang Z, Tan RX, Chen X and Li E (2015). Fungal metabolite myriocin promotes human herpes simplex virus-2 infection. Life Sciences, 120: 31-38. DOI:https://doi.org/10.1016/j.lfs.2014.11.004

Waters AM, Stafman LL, Garner EF, Mruthyunjayappa S, Stewart JE, Friedman GK, Coleman JM, Markert JM, Gillespie GY and Beierle EA (2016). Effect of Repeat Dosing of Engineered Oncolytic Herpes Simplex Virus on Preclinical Models of Rhabdomyosarcoma. Translational oncology, 9: 419-430. DOI:https://doi.org/10.1016/j.tranon.2016.07.008

Wentink GH, Frankena K, Bosch JC, Vandehoek JED and Van Den Berg T (2000). P Prevention of disease transmission by semen in cattle. Livestock Production Science, 62: 207-220. DOI:https://doi.org/10.1016/S0301-6226(99)00158-X

Yin S, Li Y, Xia H, Zhao J, Zhang Z, Tang S., Kou Z, Chen J, Yu J, Fan Z and Li T(2013). An improved system for the evaluation of antiviral compounds against herpes simplex virus type 2. Jourinal of Virolgical Methods, 189: 317-320. DOI:https://doi.org/10.1016/j.jviromet.2013.02.006

Yuqing Z, Zhan S, Jiaguo L, Deyun W, Baokang Z, Fang Y, Yunpeng F, Dan L, Xu L and Cui L (2012). Flavone ingredients can synergistically inhibit NDV infecting cell and improve ND vaccine's protective rate. International journal of biological macromolecules, 51: 201-208.

Zeedan GS, Abdalhamed AM, Ghazy AA and Ghoneim NH (2018). Serological and Molecular Identification of Infectious Bovine Rhinotrachetitis Virus Isolation and Adaptation in Embryonated Chicken Eggs. Journal of Antivirals and Antiretrovirals, 10:12-17. DOI:https://10.4172/19485964.1000174

Zeedan GSG, Allam, AMM, Nasr SM and Aballhamed AM (2014). Evaluation the efficacy of Egyptian propolis against parapox viruses by production of IFN- $\gamma$, TNF- $\alpha$ and immunoglobulin in experimental rat. World Applied Sciences journal, 31(2): 199-207. DOI:https://doi.org/10.5829/idosi.wasj.2014.31.02.82118 